\title{
ÇİMLENDİRİLMİş BAZI TAHIL VE BAKLAGİLLERİN FİZİKSEL VE KİMYASAL ÖZELLÍKLERİ
}

\author{
Fatma Nur Kılınçer, Mustafa Kürşat Demir ${ }^{* *}$ \\ Necmettin Erbakan Üniversitesi, Mühendislik ve Mimarlık Fakültesi, Gıda Mühendisliği Bölümü, Meram, \\ Konya, Türkiye
}

Geliş / Received: 08.01.2019; Kabul / Accepted: 08.04.2019; Online bask1 / Published online: 27.04.2019

Kılınçer, F.N., Demir, M.K. (2019). Çimlendirilmiş bazı tahıl ve baklagillerin fiziksel ve kimyasal özellikleri. GIDA (2019) 44 (3): 419-429 doi: 10.15237/gida.GD19019

Kulnçer, F.N., Demir, M.K. (2019). Physical and chemical properties of germinated some cereals and legumes. GIDA (2019) 44 (3): 419-429 doi: 10.15237/gida.GD19019

\section{ÖZ}

Bu çalışmada buğday, arpa, yulaf, kinoa, amarant, yeşil mercimek, nohut ve maş fasulyesi taneleri hedef alınmış olup, bu tanelerin farklı sürelerde (1, 3 ve 5 gün) çimlendirilmesi ve çimlendirme sonucunda değişimleri incelenmiştir. Çimlendirme süresi arttıkça, tanelerin $L^{*}, a^{*}$ ve $b^{*}$ değerlerinin azaldığı tespit edilmiştir. Çimlendirme ile tanelerin; kül, ham protein ve yağ miktarları artmıştır. Ham tanelere kıyasla çimlendirilmiş örneklerin, daha yüksek fenolik madde içerdiği ve çimlendirme süresinin artmasına bağlı olarak fitik asit miktarının azaldığı tespit edilmiştir. Ayrıca; baklagillerin ham protein oranının yaygın tahıllara kıyasla daha yüksek, bu tahılların da ham yağ oranının baklagillere kıyasla daha düşük olduğu ve en yüksek toplam fenolik madde içeriğine pseudo-tahıllann sahip olduğu bunu da baklagillerin takip ettiği gözlenmiştir. Sonuç olarak tahıl, pseudo-tahıl ve baklagil tanelerinin çimlendirilmesi ile mevcut kimyasal özelliklerinin geliştirilebileceği ve fonksiyonelliğinin artturlabileceği, başta tahıl ve tahıl ürünlerinde olmak üzere birçok gida üretiminde kullanılabileceği kanaatine varılmıştır.

Anahtar kelimeler: Baklagil, çimlendirme, fitik asit, tahıl.

\section{PHYSICAL AND CHEMICAL PROPERTIES OF GERMINATED SOME CEREALS AND LEGUMES}

\begin{abstract}
In this study, grains of wheat, barley, oat, quinoa, amaranth, green lentil, chickpea and mung bean were investigated in terms of their changes after germination at different times (1, 3 and 5 days). As the germination time increased, the $L^{*}, a^{*}$ and $b^{*}$ and values of the grains decreased. Germination led to increase in the amount of ash, crude protein and fat. It was found that along with the increase in germination time, the germinated samples contained higher phenolic material compared to the raw grain and decreased the amount of phytic acid. Also, crude protein in legumes was higher than common grains, that the crude fat content of common grains was lower than legumes, besides pseudocereals contained the highest amount of total phenolics which was followed by legumes. As a result, germination of grains, pseudocereals and legume grains showed that their present chemical properties and functionality can be improved and they can be used in the production of many foods, especially in cereal products.
\end{abstract}

Keywords: legume, germination, phytic acid, grain.

\footnotetext{
* Bu araştırma; Fatma Nur Kılınçer'in yüksek lisans tez çalışmasının bir bölümüdür / This paper is a part of MSc thesis of Fatma Nur Kılınçer

${ }^{* *}$ Yazışmalardan sorumlu yazar / Corresponding author;

$\bowtie$ mkdemir@erbakan.edu.tr, (1) (+90) 3323252024

司 $(+90) 3322237911$
} 


\section{GİRİ̧}

Tahıl ve baklagil taneleri, ucuz olmaları ve uzun süre bozulmadan depolanabilir özellikte olmaları nedeniyle hayvansal proteinlere iyi bir alternatif kaynak olarak görülmektedir (Ertaş, 2007). Dünyanın birçok yerinde baklagil tohumları, diyetlerde protein kaynağ1 olarak ya da diğer protein kaynaklarını tamamlayıc1 olarak kullanılmakta, hatta gelişmemiş bazı ülkelerde 'yoksul adamin eti' olarak nitelendirilmektedir (Duranti ve Gius, 1997). Tahil ve baklagil tanelerinden maksimum besin değeri elde etmek için, çimlendirme, fermantasyon, kabuk soyma, ıslatma, 1şınlama ve 1sıl işlem gibi farklı uygulamalarda yapılabilmektedir (Karaşahin, 2015, Gül vd. 2018).

Çimlenme, bitkilerin neslini devam ettirmesi için önemli bir olaydır (Evenari, 1984). Tohumdan itibaren bir bitkinin oluşumunda temel basamak çimlenmedir. Tohumda bulunan embriyo uygun şartlar bulunca tohumdan ç1karak serbest hale geçer ve gelişmeye başlar (Martinez-Villaluenga vd., 2008). Çimlenme sirasinda tohumda büyümenin başlaması ile birlikte bazı biyokimyasal ve fizyolojik değişiklikler (suyun emilmesi, enzim ve solunum faaliyeti, lipit, protein ve karbonhidrat gibi besin öğelerinin basit ve kullanılabilir forma dönüşmesi, nükleik asit ve protein sentezi, hücre farklılaşması ve büyüme gibi) meydana gelmektedir (Kanmaz ve Ova, 2014). Tohum su alınca, solunum, protein sentezi ve diğer biyokimyasal olaylar oluşmaya başlar. Böylece embriyo gelişip, radikula (kökçük) testadan çıkar ve tohum çimlenmiş olur. Kökçüğün testadan çıksş1, çimlenmenin gözle görülen bir belirtisidir. Bundan önce hormonlar ve enzimlerin etkisiyle, tohum içerisinde gözle görülmeyen birçok biyokimyasal olaylar meydana gelmektedir (Arslan, 2010). Her bitki ve tohumun bir çimlendirme şartı olup, bu da familyaya, türe ve cinse göre değişmektedir. Bu yüzden çimlendirme işlemini standardize etmek oldukça zordur. Standardizasyonda besin, 1şık, sıcaklık ve nem gibi şartlar önemlidir (Öztürk, 2008). Yapılan çalışmalarda islatma ve çimlendirme işlemleri için saf suyun tercih edildiği bildirilmiştir (Dilber vd, 2003).
Çimlendirme ile normal taneye göre besin içeriğinde önemli değişikler meydana gelmektedir. Bu değişikliklerin insan beslenmesinde önemli bir yere sahip olduğu ve içerisinde bol miktarda bulunan vitamin, mineral, enzimler ve antioksidan maddelerden dolayı bazı hastalıklara karşı da koruyucu etkisi olduğu belirlenmiştir (Finney, 1982). Dünyada çimlenmiş tane olarak en fazla; brokoli, yonca, soya, bezelye, nohut, fasulye, buğday, arpa, yulaf, karabuğday, çeltik ve lupin tüketilmektedir (Yetim vd., 2010). Günümüzde bazı baklagil, lahanagil ve turpgil familyasına ait türlerin tohumları çimlendirilmekte ve oluşan sürgünleri salata olarak tüketilmektedir. Ayrıca çimlendirilmiş tohumlar ile bu tohumların kullanıldığı kahvaltılık ürünler, salatalar, çorbalar, makarnalar, unlu mamuller gibi gidalar, endüstride yerini almaya başlamıştır (Mao vd., 2005; Márton vd., 2010). Günümüzde henüz yeni yeni kullanılan; tahıl ve baklagil tanelerinin çimlendirilme yöntemleri, aslında köklerini eski tarihlerden almaktadır. Türklerin, Orta Asya'da yaşadıkları zamanlarda çimlendirilmiş buğday ile uğut ve azık isimli tatlllar yaptıkları bilinmektedir (Dilber vd., 2003; Tangüler vd., 2015). Çin'de ise yaklaşık 5000 yll öncesinde çimlenmiş tanelerin gıda maddesi olarak tüketildiği, 1700’lü yıllarda yolculukları sırasında skorbüt hastalı̆̆ına yakalanan denizcilerin tedavisinde baklagil çimlerinin kullanıldığ1 bilinmektedir (Yang vd., 2001). Günümüzde insanlar, yapay katk1 içermeyen, doğal veya az işlem görmüş gıdalara yönelmektedir. Bazı tahıl ve baklagil çimlerinin biyoaktif bileşenlerce zengin olması, bunların fonksiyonel gıda veya gıda bileşeni olarak endüstride kullanımının yaygınlaşmasını mümkün kılmaktadır. Diğer bir deyişle, çimlenmiş tane katkılı gıdalarda besin değerinin yanısıra, fonksiyonellik ve dayanıklılıkta artmaktadır (Siro vd., 2008). Bu çalışma; gida sektörüne daha fonksiyonel nitelikte yeni alternatiflerin kazandırılması amacıyla planlanmış, bu amaçla da bazı tahil ve baklagillerin çimlendirilmesiyle meydana gelen fiziksel ve kimyasal değişimler incelenmiştir.

\section{MATERYAL VE YÖNTEM \\ Materyal}

Çalışmamızda çimlendirilmek üzere kullanılan; ekmeklik buğday, yulaf, arpa (Demirhan Gida 
San. Tic. Ltd. Şti., Konya, Türkiye), kinoa, amarant, maş fasulyesi, yeşil mercimek ve koçbaşı nohut (Yayla Agro Gıda Sanayi ve Nakliyat A.Ş., Mersin, Türkiye), piyasadan temin edilmiştir.

\section{Yöntem}

\section{Deneme Planı}

Denemelerde; 8 farklı tahil ve baklagil tanesi (buğday, yulaf, arpa, kinoa, amarant, yeșil mercimek, nohut ve maş fasulyesi) ile 3 farklı çimlendirme süresi (1., 3. ve 5. gün) esas alınmış, elde edilen veriler kontrol grubu olarak çimlendirilmemiş (0. gün) örnekler ile kıyaslanmıştır. Denemeler (8 x 4) x 2 faktöriyel deneme desenine göre yürütülmüsstür.

\section{Çimlendirme Prosesi}

Buğday (ekmeklik), yulaf, arpa, kinoa, amarant, yeşil mercimek, nohut, maş fasulyesi örnekleri ilk olarak saf su ile yıkanıp, süzülmüş ve temizlenmiştir. Çimlendirme sırasında gelişmesi muhtemel mikrobiyal faaliyeti engellemek için, $100 \mathrm{~g}$ örnek $500 \mathrm{ml}$ sodyum hipoklorit (\%20'lik) içerisinde 20 dakika süreyle bekletilerek sterilize edilmiş ve ardından saf suyla yıkanarak nötralizasyonu gerçekleştirilmiştir. Sterilize edilmiş bu tanelerin üzerine 3 katı olacak şekilde saf su ilave edilmiş ve 24 saat süreyle, oda sicaklığında $\left(24 \pm 1{ }^{\circ} \mathrm{C}\right)$ karanlı bir ortamda 1slatılmaya bırakılmıştır. Islatma süresi sonunda taneler süzülerek, tülbent ve pamuktan oluşan iki katman arasına yerleştirilmiştir. Tanelerin yerleştirilirken ince bir tabaka halinde serilmesine ve birbirine temas etmemesine dikkat edilmiştir. 12 saatte bir, taneler saf sudan geçirilmiş, 1., 3. ve 5. günlerinin sonunda da çimlenme işlemleri durdurulmuştur. Çimlendirilmiş taneler analize alınmadan önce, birbirine yapışmayacak şekilde, kurutma kâğttlarının üzerinde tepsilere dizilerek; $50{ }^{\circ} C^{\prime}$ lik bir etüvde (Nüve FN-400, Ankara, Türkiye) kurutulmuş ve ardından laboratuvar tipi bir öğütücüde öğütülmüştür. Boyut kontrolü amacıyla da, ögütülmüş tüm örnekler, $500 \mu^{\prime}$ luk bir elek yardımıyla elenmiş, hava geçirmeyecek şekilde kilitli polietilen poşetler içerisinde soğutucuda $\left(-18^{\circ} \mathrm{C}\right)$ muhafaza edilmiştir.

\section{Renk Analizleri}

Ham ve çimlendirilmiş örneklerin renkleri, Hunter Lab Color Quest II Minolta CR-400
(Konica Minolta Sensing, Inc., Osaka, Japonya) cihazı kullanılarak $L^{*}$ değeri $[(0)$ siyah-(100) beyaz], $a^{*}$ değeri [(+) kırmızı- (-) yeşil] ve $b^{*}$ değeri $[(+)$ sar1-(-) mavi] cinsinden ölçülmüştür (Francis, 1998).

\section{Kimyasal Analizleri}

Kül tayini AACC 08-01'e, ham yağ miktarı otomatik yağ ekstraksiyon cihazında (Velp SER 148/6, Usmate, İtalya) AACC 30-25'e göre belirlenmiştir (AACC, 1990). Ham protein tayini; Kjeldahl yöntemiyle, AACC 46-12'ye göre yapılmışır (AACC, 1990). Örneklerin protein miktarları hesaplanırken; buğday için $\mathrm{N}$ x 5,7; arpa ve yulaf için $\mathrm{N} x$ 5,83; kinoa, amarant, yeşil mercimek, nohut ve maş fasulyesi için $\mathrm{N} \times 6,25$ çarpım faktörü kullanılmıştır. Ham ve çimlendirilmiş örneklerin toplam fenolik madde içeriği, Folin-Ciocaltaeu Metodu kullanılarak kolorimetrik olarak tayin edilmiştir. Tüm örnekler (3 g), asitlendirilmiş metanol $(\mathrm{HCl} / \mathrm{metanol} / \mathrm{su}$, $1: 80: 10, \mathrm{v} / \mathrm{v})$ içerisinde $(15 \mathrm{ml}), 2.5$ saat süre ile çalkalamalı su banyosunda $\left(24 \pm 1^{\circ} \mathrm{C}\right)$ çalkalanarak ekstrakte edilmiştir. Daha sonra bu karışım, 3000 rpm'de 10 dakika süre ile santrifüj edilmiş ve sonrasinda elde edilen supernatant kullanilarak toplam fenolik madde içeriği tespit edilmiştir. Analizde $0.8 \mathrm{ml}$ supernatant örnek, $4.8 \mathrm{ml}$ saf su, $0.5 \mathrm{ml}$ Folin-Ciocaltaeu reaktifi (\%10'luk, h/h, suda) ve $1 \mathrm{ml}$ sodyum karbonat çözeltisi (\% 20'lik, $\mathrm{a} / \mathrm{h}$, suda) deney tüpünde karıştırılmış ve ardından 2 saat oda sıcaklığında $\left(24 \pm{ }^{\circ} \mathrm{C}\right)$ 1şı görmeyen bir yerde inkübe edilmiştir. Bu süre sonunda da çözeltilerin absorbans değerleri $725 \mathrm{~nm}$ de spektrofotometrede (Libra S60, Biochrom Ltd., Cambridge, İngiltere) okunmuş ve toplam fenol miktarı gram ekstrede ìg gallik asite (ig GAE/g) eşdeğer olacak şekilde hesaplanmıştır (Slinkard ve Singelton, 1977; Gamez-Meza vd., 1999).

Fitik asit miktan tayini, Haug ve Lantzsch (1983)'e göre, kolorimetrik metot kullanılarak yapılmıştır. Örnekteki fitik asit, $0.2 \mathrm{~N}$ hidroklorik asit çözeltisi ile ekstrakte edildikten sonra Demir III çözeltisi ile muamele edilip, çöktürülmüştür. Serum kısmında kalan demir miktarı spektrofotometrik (519 nm) yolla belirlenmiş ve bundan fitik asit miktarı hesaplaması yapılmıştır. Sonuçlar $\mathrm{mg} / 100 \mathrm{~g}$ cinsinden ifade edilmiştir. 


\section{İstatistiksel Analizler}

Denemeler; 2 tekerrürlü olarak yürütülmüş olup, araştırma sonucunda elde edilen verilerin istatistiki analizinde JMP istatistik programı (14.0.1 versiyon, SAS Institute Inc., Cary, NC, ABD) kullanılmışır. Elde edilen veriler varyans analizine tabi tutulmuş, farklılıkları istatistiki olarak önemli bulunan ana varyasyon kaynaklarının ortalamaları ise, Duncan çoklu karşılaştırma testi ile $(P<0.05)$ kıyaslanmıştır (Düzgüneş vd., 1987).

\section{BULGULAR VE TARTIŞMA \\ Renk Analizi}

$\mathrm{Bu}$ çalışmada; ham ve çimlendirilmiş 8 farklı örneğin $L^{*}$ değerleri 75.31-86.72; $a^{*}$ değerleri $-3.01-1.00 ; b^{*}$ değerleri ise $14.48-22.18$ arasinda değişim göstermiştir. Öztürk (2008) çimlendirilmiş buğday üzerine yaptığ çalışmasında, ham ve çimlendirilmiş buğdayların $L^{*}$ değerinin $63.85-77.37 ; a^{*}$ değerinin 3.5-7.12 ve $b^{*}$ değerinin ise 13.77-25.84 arasında değiştiğini bildirmiştir. Tian vd. (2010) çimlendirilmiş yulaf üzerine yaptıkları bir çalışmalarında; örneklerin $L^{*}$ değerinin 54.77-80.36; $a^{*}$ değerinin 2.37-8.80 ve $b^{*}$ değerinin 9.76-21.75 arasında değiştiğini tespit etmişlerdir. Tok (2017) da bir çalışmasında, çimlendirilmiş buğday ve yeşil mercimek örneklerinin $L^{*}$ değerlerini 76.77-87.53; $a^{*}$ değerlerini $-1.68-2.71 ; b^{*}$ değerlerinin ise 9.3225.34 arasında değişim gösterdiğini bildirmiştir. Elde ettiğimiz sonuçlar, bu literatür bilgileri örtüşmektedir. Duncan çoklu karşılaştırma testi sonuçlarına göre (Çizelge 1); çimlendirilmiş taneler arasında; en yüksek $L^{*}$ değeri ortalaması nohut örneğinde iken, en düşük $L^{*}$ değeri ortalaması maş fasulyesi örneklerinde tespit edilmiştir. Aynı zamanda maş fasulyesi örneklerinin en düşük $a^{*}$ değeri ortalamasına sahip olduğu da gözlenmiştir. En yüksek $a^{*}$ değeri ortalaması ise buğday örneklerinde tespit edilmiştir. En yüksek $b^{*}$ değerleri ortalaması yeşil mercimek örneğinde, en düşük $b^{*}$ değeri ortalaması ise kinoa örneklerinde tespit edilmiştir. Çimlenmemiş ham örneklere göre; çimlendirme işlemi ve süresiyle, $L^{*}, a^{*}$ ve $b^{*}$ değerlerinin istatistiki olarak $\left(\begin{array}{ll}P & <0.05\end{array}\right)$ azaldığ1 tespit edilmiştir. Çimlendirilen örneklerde, 3. gün sonrası rengin bariz bir şekilde koyulaştığ1 belirlenmiştir. Ayrıca ham tanelere göre, çimlendirme ile tanenin yeşil akşamların da artmasına bağlı olarak, $a^{*}$ değerinin negatif değerler verdiği yani yeşilliğin arttı̆̆1 tespit edilmiştir.

Çizelge 1. Tanelerin renk özellikleri üzerine çimlenmenin etkisi ${ }^{1}$

Table 1. Effect of germination on the color properties of

\begin{tabular}{lccc}
\multicolumn{4}{c}{ seeds } \\
\hline $\begin{array}{l}\text { Parametreler } \\
\text { Parameters }\end{array}$ & \multicolumn{1}{c}{$\boldsymbol{L}^{*}$} & $\boldsymbol{a}^{*}$ & $\boldsymbol{b}^{\boldsymbol{*}}$ \\
$\begin{array}{l}\text { Çimlendirilmiş taneler } \\
\text { Germinated seeds }\end{array}$ \\
$\begin{array}{l}\text { Buğday } \\
\begin{array}{l}\text { Wheat } \\
\text { Arpa } \\
\text { Barley }\end{array}\end{array}$ & $80.11^{\mathrm{e}}$ & $0.52^{\mathrm{b}}$ & $19.75^{\mathrm{d}}$ \\
$\begin{array}{l}\text { Yulaf } \\
\text { Oat }\end{array}$ & $82.98^{\mathrm{d}}$ & $0.46^{\mathrm{c}}$ & $16.45^{\mathrm{f}}$ \\
$\begin{array}{l}\text { Kinoa } \\
\text { Quinoa }\end{array}$ & $83.73^{\mathrm{c}}$ & $0.17^{\mathrm{c}}$ & $16.43^{\mathrm{f}}$ \\
$\begin{array}{l}\text { Amarant } \\
\text { Amaranth }\end{array}$ & $84.67^{\mathrm{b}}$ & $0.13^{\mathrm{c}}$ & $14.48^{\mathrm{g}}$ \\
$\begin{array}{l}\text { Yeşil mercimek } \\
\text { Green Lentil }\end{array}$ & $79.83^{\mathrm{f}}$ & $1.00^{\mathrm{a}}$ & $21.23^{\mathrm{b}}$ \\
$\begin{array}{l}\text { Nohut } \\
\text { Chickpea }\end{array}$ & $76.71 \mathrm{~g}$ & $-1.89^{\mathrm{d}}$ & $22.18^{\mathrm{a}}$ \\
$\begin{array}{l}\text { Maş Fasulyesi } \\
\text { Mung Bean }\end{array}$ & $86.72^{\mathrm{a}}$ & $0.11^{\mathrm{c}}$ & $20.80^{\mathrm{c}}$ \\
\hline
\end{tabular}

Çimlendirme Süresi (gün)

Germination Time (day)

\begin{tabular}{llll}
\hline 0. & $82.91^{\mathrm{b}}$ & $-0.17^{\mathrm{ab}}$ & $20.33^{\mathrm{a}}$ \\
1. & $83.41^{\mathrm{a}}$ & $-0.07^{\mathrm{a}}$ & $18.05^{\mathrm{c}}$ \\
3. & $81.57^{\mathrm{c}}$ & $-0.24^{\mathrm{b}}$ & $17.55^{\mathrm{d}}$ \\
5. & $77.14^{\mathrm{d}}$ & $-0.75^{\mathrm{c}}$ & $19.16^{\mathrm{b}}$ \\
\hline
\end{tabular}

${ }^{1}$ Aynı satırda farklı harf taşıyan ortalamalar birbirinden farklı $(P<0.05)$, aynı harf taşıyan ortalamalar farksizdir $(P>0.05)$.

${ }^{1}$ Averages with different letters on the same row are different from each other $(P<0.05)$, averages with same letter are not different $(P>0.05)$.

Elde edilen bu sonuçlarımızı destekleyici olarak; Öztürk (2008) ham buğday tanesinin $L^{*}$ değerinin 77.37'den, çimlendirme ile 63.85'e azaldığını, Tok (2017) çimlendirme süresi arttıkça örneklerin parlaklık değerlerinde azalma gerçekleştiğini bildirmiştir. Yaqoob vd. (2018)' de; çimlendirilmiş 
arpa ilaveli kek karışımının $L^{*}$ ve $b^{*}$ değerinin azaldığ1 tespit etmiştir. $\mathrm{Bu}$ durumun olas1 nedenleri arasinda, çimlendirilen tanelerin çeşitliliği ve çimlendirme süreleri olarak siralanabilir.

\section{Kimyasal Analizler \\ Kül}

Ham ve çimlendirilmiş örneklerin kül değeri ortalamaları \% $\quad 1.34-3.41$ arasında değişim göstermiştir. Farooqui vd. (2018), arpa çimlendirilmesi üzerine yaptıkları bir çalışmalarında; kül değerlerinin \% 1.56-1.80 arasında değişim gösterdiğini tespit etmişlerdir. Donkor vd. (2012) tahılların çimlendirilmesine yönelik bir çalışmalarında; buğday kül değerleri dağılımının \% 1.85 ile $\% 2.18$, yulafin ise $\% 1.56$ ile \% 1.77 arasında değişim gösterdiğini tespit etmişlerdir. Ghavidel ve Prakash (2007) çimlendirilmiş baklagil özelliklerini inceledikleri bir çalışmalarında; maş fasulyesi kül değerlerinin $\% 3.88$ ile \% 4.03; mercimeğin \% 2.28 ile 2.44, nohutun \% 2.94 ile \% 3.14 arasında değiştiğini belirlemişlerdir. Elde ettiğimiz sonuçları, bu literatür bilgileri desteklemektedir. Duncan çoklu karşılaştırma testi sonuçlarına göre (Çizelge 2); amarant, yeşil mercimek ve nohut örneklerinin ortalama kül değerleri istatistiki olarak önemsiz bulunmuştur $(P>0.05)$. En düşük kül miktarı ortalaması yulaf örneklerinde iken, en yüksek kül değeri ortalaması maş fasulyesi örneklerinde tespit edilmiştir. Çimlenmemiş tüm tanelerin ortalama kül içeriğinin \% 2.19 olduğu, 5 günlük çimlendirme işlemi sonunda ise ortalama kül değerlerinin \% 2.26'ya çıktığ1 tespit edilmiştir. Özelliklede çimlendirme süresinin artmasina (3.gün sonrası) bağlı olarak; tahıl ve baklagil taneleri kül değerlerinin, ham taneye kıyasla daha yüksek olduğu belirlenmiştir. Çimlenme sırasında; fitaz enzim aktivitesindeki değişimlere bağlı olarak kül değerlerinde artma ve azalmalar gerçekleşmektedir. Fitaz enzimi, protein ve minerallerin bağlı bulunduğu yapıları hidrolize ederek, minerallerin serbest kalmasinı sağlamaktadır (Narsih, 2012). Ayrica bazı araştırmacılar, tahıl ve baklagil tanelerin mineral alımına izin veren radiksin (kök) uzantısının gelişmesiyle kül içeriğinin 4. günden itibaren arttığını ifade etmektedirler (Sneath ve McIntosh, 2003).
Kavas ve El (1991), çimlendirilmiş mercimeğin besleyici değerlerini araştırdıkları bir çalışmalarında; çimlendirilmemiş mercimeğin kül içeriğinin \% 2.62 olduğunu, 4 gün çimlendirmesi ile de bu oranın \% 2.85' e yükseldiğini tespit etmişlerdir. Fouad ve Rehab (2015), çimlendirilmemiş yeşil mercimekte kül oranının \% 2.77 olduğunu, 6 gün süreyle çimlendirilmesi sonucunda ise bu oranın \% 3.35 değerine çıktı̆̆ını bildirmişlerdir. Kanmaz (2017)'da, 5 günlük çimlendirmiş buğday tanelerinde kül içeriğinin \% 18 arttığını bildirmiştir. Çimlenme işlemi esnasinda tanenin kimyasal kompozisyonundaki değişikliklerin araştırıldığı birçok çalışma mevcuttur. Çimlenmeyle artan alfa amilaz etkisiyle, ilk olarak karbonhidratlar yıkıma uğramakta ve solunumda kullanılmak üzere basit şekerlere dönüşmektedir. Bu durum; kimyasal kompozisyonda yer alan diğer bileşenlerin oransal artışına da neden olmaktadır (Jones ve Jacobsen, 1991; Garciarubio vd., 1997).

\section{Ham protein}

Ham ve çimlendirilmiş örneklerin, ham protein değerleri \% 8.97 ile \% 24.45 arasında değişim göstermiştir (Çizelge 2). Harmuth-Hoene vd. (1987), buğday, maş fasulyesi ve nohut tanelerini çimlendirdikleri bir çalışmalarında, ham protein oranlarinin sirasiyla, \% 10.38 -10.62; \% 23.0423.80 ve \% 20.15-20.33 arasında değişim gösterdiğini bildirmiştir. Tian vd. (2010), ham ve çimlendirilmiş yulaf tanelerinde ham protein oranının \% 18.98-22.02 arasında olduğunu tespit etmișlerdir. Chauhan vd. (2015) yapmış oldukları bir çalışmalarında; ham ve çimlendirilmiş amarant örnekleri ham protein değerlerinin \% 15.05-16.5 arasında değiştiğini bildirmişlerdir. Duncan çoklu karşılaştırma testi sonuçlarına göre (Çizelge 2); ham protein değerlerinin, çimlendirilmiş taneler arasında baklagil örneklerinde daha yüksek olduğu belirlenmiştir. En yüksek ham protein ortalaması yeşil mercimekte tespit edilmişken, onu sırasıyla maş fasulyesi ve nohut izlemiştir. En düşük ham protein oranının ise arpa örneğinde olduğu belirlenmiştir. Elde edilen sonuçlar genel olarak değerlendirildiğinde; baklagillerin ham protein oranının tahıllara kıyasla daha yüksek olduğu tespit edilmiştir. Ayrıca; çimlendirme işlemi ve süresine bağlı olarak ham protein miktarının, çimlendirilmemiş (ham) örneklere göre, istatistiki 
olarak $(P<0.05)$ arttığ tespit edilmiştir. Çimlenme sirasinda, tanenin yapisinda bulunan proteaz enziminin aktive olmasi; proteinlerin oligopeptitlere, peptitlere ve serbest aminoasitlere parçalanmasını sağlamaktadır. Çimlenme ve filizlerin büyümesi ile birlikte tanede; yeni protein, aminoasit ve nükleik asit (DNA ve RNA) sentezi de gerçekleşmektedir (Kanmaz, 2017). Aynı zamanda çimlenmeyle birlikte tanede gerçekleşen nitratların emilimi, karbonhidrat rezervlerinden azotlu bileşiklerin metabolizmasını kolaylaştırır ve böylece tanelerin ham protein seviyeleri de artar (Sneath ve McIntosh, 2003). Fakat her tahil ve her baklagildeki bu artışlar farklılık arzedebilmektedir. Bunun muhtemel sebebi de ham maddenin çimlenme fizyolojilerindeki değişikliklerden kaynaklanmaktadır. Kavas ve El (1991) mercimeklerde protein oranlarının \% $30.0 \pm 0.27$ olduğunu, çimlendirilmesi ile de bu oranın \% $33.28 \pm 0.89$ ' e çıktığını tespit etmiştir. Bibi vd. (2008) nohut örneklerinde ham protein oranlarının \% 19.84 olduğunu, çimlendirmeyle de bu oranların \% 21.97'e yükseldiğini bildirmişlerdir. Fouad ve Rehab (2015), mercimekte $23.65 \mathrm{~g} / 100 \mathrm{~g}$ olan protein miktarının $3,4,5$ ve 6 günlük çimlenme sonucunda sirasıyla $27.51 ; 27.90 ; 28.41$ ve $28.86 \mathrm{mg} / 100$ g'e arttı̆̆ın tespit etmişlerdir. $\mathrm{Bu}$ artışın sebebi olarak çimlenme esnasında gerçekleşen solunumla birlikte, karbonhidratların yıkımından kaynaklanan kuru madde kaybı gösterilmektedir (Mahmoud ve El-Anany, 2014; Uppal ve Bains, 2012). Nonogaki vd. (2010) ise protein miktarındaki artışı sebebini çimlenme sürecindeki hormonal değişimler ve imbibisyon sirasinda yeni protein sentezi olarak açıklamaktadır.

Çizelge 2. Tanelerin kimyasal özellikleri üzerine çimlenmenin etkisi ${ }^{1}$ Table 2. Effect of germination on the chemical properties of seeds

\begin{tabular}{|c|c|c|c|c|c|}
\hline $\begin{array}{l}\text { Parametreler } \\
\text { Parameters }\end{array}$ & $\begin{array}{l}\text { Kül (\%) } \\
\text { Ash (\%) }\end{array}$ & $\begin{array}{l}\text { Ham Protein }(\%) \\
\text { Crude Protein (\%) }\end{array}$ & $\begin{array}{l}\text { Ham Yağ }(\%) \\
\text { Crude Fat }(\%)\end{array}$ & $\begin{array}{c}\text { Fitik asit }(\mathrm{mg} / 100 \mathrm{~g}) \\
\text { Phytic acid } \\
(\mathrm{mg} / 100 \mathrm{~g})\end{array}$ & $\begin{array}{c}\text { Toplam Fenolik Madde } \\
\text { ( } \mu \mathrm{g} \text { GAE/g) } \\
\text { Total phenolic content } \\
(\mu g G A E / g)\end{array}$ \\
\hline \multicolumn{6}{|c|}{$\begin{array}{l}\text { Çimlendirilmiş taneler } \\
\text { Germinated seeds }\end{array}$} \\
\hline $\begin{array}{l}\text { Buğday } \\
\text { Wheat }\end{array}$ & $1.34^{\mathrm{f}}$ & $15.87^{\mathrm{d}}$ & $1.77^{f}$ & $789.20^{\mathrm{b}}$ & $1378.38 \mathrm{~g}$ \\
\hline $\begin{array}{l}\text { Arpa } \\
\text { Barley }\end{array}$ & $1.92^{\mathrm{d}}$ & $8.97^{\mathrm{h}}$ & $1.98^{\mathrm{e}}$ & $681.69^{d}$ & $1445.45^{\mathrm{f}}$ \\
\hline $\begin{array}{l}\text { Yulaf } \\
\text { Oat }\end{array}$ & $1.67^{e}$ & $13.09^{\mathrm{f}}$ & $6.63^{a}$ & $631.08^{\mathrm{e}}$ & $1720.76^{\mathrm{e}}$ \\
\hline $\begin{array}{l}\text { Kinoa } \\
\text { Quinoa }\end{array}$ & $2.13^{c}$ & $13.96^{\mathrm{e}}$ & $4.69^{c}$ & $671.57^{\mathrm{d}}$ & $2205.12^{b}$ \\
\hline $\begin{array}{l}\text { Amarant } \\
\text { Amaranth }\end{array}$ & $2.34^{b}$ & $11.04 \mathrm{~g}$ & $5.30^{\mathrm{b}}$ & $392.29^{f}$ & $2376.59^{a}$ \\
\hline $\begin{array}{l}\text { Yeşil mercimek } \\
\text { Green Lentil }\end{array}$ & $2.30^{\mathrm{b}}$ & $24.45^{\mathrm{a}}$ & $0.86 \mathrm{~g}$ & $928.37^{a}$ & $2051.70^{c}$ \\
\hline $\begin{array}{l}\text { Nohut } \\
\text { Chickpea }\end{array}$ & $2.30^{\mathrm{b}}$ & $21.11^{\mathrm{c}}$ & $4.42^{\mathrm{d}}$ & $727.62^{c}$ & $1768.43^{\mathrm{d}}$ \\
\hline $\begin{array}{l}\text { Maş Fasulyesi } \\
\text { Mung Bean }\end{array}$ & $3.41^{\mathrm{a}}$ & $23.95^{\mathrm{b}}$ & $0.90 \mathrm{~g}$ & $363.36 \mathrm{~g}$ & $1714.95^{\mathrm{e}}$ \\
\hline \multicolumn{6}{|c|}{$\begin{array}{l}\text { Çimlendirme Süresi (gün) } \\
\text { Germination Time (day) }\end{array}$} \\
\hline 0. & $2.19^{b}$ & $14.73^{c}$ & $3.13^{c}$ & $935.66^{a}$ & $1372.12^{\mathrm{d}}$ \\
\hline 1. & $2.06^{c}$ & $17.80^{a}$ & $3.35^{\mathrm{b}}$ & $798.94^{b}$ & $1564.94^{c}$ \\
\hline 3. & $2.19^{b}$ & $16.80^{\mathrm{b}}$ & $3.34^{\mathrm{b}}$ & $555.32^{c}$ & $1952.14^{\mathrm{b}}$ \\
\hline 5. & $2.26^{\mathrm{a}}$ & $16.90^{\mathrm{b}}$ & $3.46^{\mathrm{a}}$ & $302.67 \mathrm{~d}$ & $2441.49^{a}$ \\
\hline
\end{tabular}

${ }^{1}$ Aynı satırda farklı harf taşıyan ortalamalar birbirinden farklı $(P<0.05)$. Aynı harf taşıyan ortalamalar farksızdır $(P>0.05)$. ${ }^{1}$ Averages with different letters on the same row are different from each other $(P<0.05)$. Averages with same letter are not different $(P>0.05)$ 
Ham yağ Çizelge 2 incelendiğinde, ham ve çimlendirilmiş örneklerde ham yağ değerlerinin \% 0.86-6.63 arasında değişim gösterdiği görülmektedir. Ghavidel ve Prakash (2007) baklagilleri çimlendirdikleri bir çalışmalarında; maş fasulyesi, mercimek ve nohut tanelerinde ham yağ oranlarının sırasıyla; \% 1.21-1.29; \% 0.780.89; \% 5.18-5.45 arasında değişim gösterdiğini bildirmişlerdir. El-Adawy vd. (2003) maş fasulyesini çimlendirdikleri bir çalışmada; ham yağ oranının \% 1.15-1.75 arasında değiştiğini belirlemişlerdir. Donkor vd. (2012)'de çeşitli tahılları çimlendirdikleri bir çalışmalarında; buğdayın ham yağ oranının \% 1.81-1.95, arpanın $\%$ 2.37-3.01, yulafin ise \% 2.37-3.01 arasinda değiştiğini bildirmişlerdir. Çizelge 2'ye göre; en yüksek ham yağ değerleri yulaf örneklerinde tespit edilmiş olup, bunu sırasıyla amarant ve kinoa taneleri takip etmiştir. Yeşil mercimek ve maş fasulyesi örneklerinin ise, en düşük ham yăg değerlerine sahip oldukları belirlenmiştir. Elde edilen sonuçlar genel olarak değerlendirildiğinde; baklagil ham yağ oranlarının tahıllara kıyasla daha düşük olduğu, tanelerde çimlendirme süresinin artması bağlı olarak ham yağ miktarının da arttığ tespit edilmiştir. Çimlenme sırasinda tohumun yapisinda bulunan lipaz enziminin aktive olması, yağların yağ asitlerine ve gliserole parçalanmasını sağlamaktadır. Buna karşın çimlendirilmiş tanelerin toplam yağ içeriği, ham tanelere kıyasla önemli artış göstermektedir. Çimlenmenin ileri aşamalarında, tanenin çeşidine göre farklı düzeylerde olmak üzere, yeniden yağ ve yağ asitleri sentezi gerçekleşmektedir (Kanmaz, 2017). Finney (1982); 3 gün çimlendirilen buğday örneklerinde ham yağ içeriğinin \% 0.95 'ten \% 1.54'e yükseldiğini bildirmiştir. Öztürk (2008)' de buğdayın çimlenmesi ile ham yağ miktarında yaklassık olarak \% 20 civarında bir artış meydana geldiğini tespit etmiştir. Bibi vd. (2008), çimlenme süresince tanelerin yağ oranlarında doğrusal bir artış gözlemlediklerini, nohut örneklerinin ham yağ oranının \% 4.24'ten \% 6.03'ye yükseldiğini bildirmişlerdir.

\section{Fitik asit}

Ham ve çimlendirilmiş tanelerin fitik asit içerikleri 363.36 ile $928.37 \mathrm{mg} / 100 \mathrm{~g}$ arasında değişim göstermiştir. Ghavidel ve Prakash (2007); ham ve çimlendirilmiş maş fasulyesi, mercimek ve nohut tanelerinindeki fitik asit miktarlarının sırası ile $500-610,150-190$ ve $380-480 \mathrm{mg} / 100 \mathrm{~g}$ arasinda olduklarını belirlenmiştir. Tok (2017), ham ve çimlendirilmiş buğdayın fitik asit içeriğini 332$1276 \mathrm{mg} / 100 \mathrm{~g}$, yeşil mercimeğin ise 306-1474 $\mathrm{mg} / 100 \mathrm{~g}$ arasında değişim gösterdiğini tespit etmiştir. Duncan çoklu karşılaştırma testi sonuçlarına göre (Çizelge 2); çimlendirilmiş taneler arasında; yeşil mercimek örneklerinin en yüksek, maş fasulyesi örneklerinin ise en düşük fitik asit değerlerine sahip olduğu belirlenmiştir. Çimlendirme süresi arttıkça, örneklerin istatistiki olarak $(P<0.05)$ fitik asit miktarının da azaldığ tespit edilmiştir. Çimlenme işlemi, tohumların yapisında bulunan anti-besinsel bileșenlerin miktarını azaltan en önemli proseslerden biridir. Çimlenmeyle artan fitaz enzimi aktivitesi sebebiyle fitik asit miktarı önemli oranda düşmekte ve minerallerin biyoyararll1lı̆g1 artmaktadır. Yaklaşık 7 ile 8 günlük çimlendirme işlemi sonunda fitat içeriğinin neredeyse tamamının parçalandığı bilinmektedir (Ashton ve Williams 1958). Harmuth- Hoene vd. (1987), buğday, maş fasulyesi ve nohutta fitik asit içeriklerinin sırasıyla $878.2 \mathrm{mg} / 100 \mathrm{~g}, \quad 628.8$ $\mathrm{mg} / 100 \mathrm{~g}$ ve $338.3 \mathrm{mg} / 100 \mathrm{~g}$ olduğunu, bu tanelerinin çimlendirmeyle birlikte yine sırasıyla $571.2 \mathrm{mg} / 100 \mathrm{~g} ; 378.7 \mathrm{mg} / 100 \mathrm{~g}$ ve 327.8 $\mathrm{mg} / 100 \mathrm{~g}$ değerlerine düştüğünü tespit etmişlerdir. Ghavidel ve Prakash (2007) mercimek, börülce, manş fasulyesi ve nohut gibi bazı baklagiller ile yaptıkları çimlenme çalışmalarında, fitik asit miktarının \% 18 ile 21 oranında azaldığını belirlemişlerdir. Bu çalışmada $\mathrm{da}$, tanelerin çimlendirilmesi sonucunda fitik asit miktarlar1 $935.36 \quad \mathrm{mg} / 100 g^{\prime}$ dan, $\quad 302.67$ mg/100g'a düşmüştür.

\section{Toplam fenolik madde}

Çizelge 2 incelendiğinde, ham ve çimlendirilmiş tanelerdeki toplam fenolik madde miktarlarının 1378.38 ile $2376.59 \mu \mathrm{g}$ GAE/g arasında değiştiği açıçça görülmektedir. Pasko vd. (2009), ham ve çimlendirilmiş amarant ve kinoa tanelerindeki toplam fenolik madde miktarının 2950-3750 $\mu \mathrm{g}$ $\mathrm{GAE} / \mathrm{g}$ arasında değişim gösterdiğini bildirmişlerdir. Bir başka çalışmada ise, ham ve çimlendirilmiş maş fasulyesindeki toplam fenolik 
madde düzeyleri 1665-1917 $\mu \mathrm{g}$ GAE/g arasinda değişim göstermiş̧iir (Kim vd., 2012). Elde edilen verilere göre (Çizelge 2); çimlendirilmiş taneler arasında en yüksek toplam fenolik madde miktarı amarant tanelerinde elde edilmiş olup, bunu sırasıyla kinoa, yeşil mercimek ve nohut taneleri takip etmiştir. En düşük toplam fenolik madde miktarları ise, buğday örneğinde tespit edilmiştir. Sonuçlar genel olarak değerlendirildiğinde; en yüksek toplam fenolik madde içeriğini pseudotahılların (kinoa ve amarant) verdiği, bunu baklagillerin takip ettiği ve yaygin tahıl olarak bilinen buğday ve arpanın ise en düşük toplam fenolik madde içeriğe sahip olduğu belirlenmiştir. Baklagil taneleri kendi arasında kıyaslandığında ise; yeşil mercimeğin en yüksek toplam fenolik içeriğine sahip olduğu görülmektedir. Bunun nedeni ise; Fratianni vd. (2014) tarafindan, mercimekte kotiledonun flavonoid olmayan fenolik bileşikleri (hidroksibenzoik ve hidroksisinnamik asitler), kabuk tabakasınında ise flavonoidleri içermesi olarak açiklanabilir. Çimlendirme süresi artmasıly birlikte, tanelerdeki toplam fenolik madde miktarının arttığ1 da belirlemiştir. Tohumların çimlenmesi ile, birincil ve ikincil metabolitler kompozisyonundaki antioksidan ve toplam fenolik maddelerde radikal değişiklikler meydana gelmektedir (Xu vd., 2009). Özellikle de çimlendirilme işlemi ile, antioksidan özellikli fenolik bileşik miktarının arttırılması başarılı bir strateji olarak görülmektedir (Dziki vd., 2015). Çimlenme işlemiyle birlikte yeni bileşiklerin sentezi artmakta ve toplam fenolik madde miktarı da bu prosesle beraber artış göstermektedir. Çimlendirme süresinin artmasına bağlı olarak, toplam fenolik madde miktarının artmasının sebebi de, bu yeni bileşiklerini sentezlenmesinden ileri gelmektedir. Randhir vd. (2004), 1 günlük maş fasulyesi çimlerinin \% 20, 4 günlük çimlerinin ise $\% 46$ oranında daha yüksek fenolik madde içerdiğini ve böylelikle antioksidan ve antimikrobiyal özellik bakımından daha zengin hale geldiklerini tespit etmisslerdir. Alvarez-Jubete vd. (2010); çimlendirilmemiş amarant tanesindeki toplam fenolik madde içeriğinin $212 \mu \mathrm{g} \mathrm{GAE} / \mathrm{g}$, aynı tane çimlendiğinde ise bu miktarın $822 \mu \mathrm{g}$ $\mathrm{GAE} / \mathrm{g}$ ulaştığını tespit etmişlerdir. Bu literatür bilgileri de çalışmamızı destekler niteliktedir.

\section{SONUÇ}

$\mathrm{Bu}$ araştırmada ülkemizde yayginca yetiştirilen ve yetiştirilmeye başlanılan bazı tahıl, pseudo-tahıl ve baklagil çeşitleri ile bunların çimlendirilmesi sonucunda elde edilen son ürünlerin, çimlendirme süresine bağlı olarak değişimlerinin belirlenmesi amaçlanmıştır. Yapılan bu araştırma neticesinde;

Çimlendirme süresinin artmasına bağlı olarak; $L^{*}$, $a^{*}$ ve $b^{*}$ değerlerinin azaldı̆̆1 tespit edilmiştir. Çimlenmeyle tanelerde renk değişimleri meydana gelmiş, çimlendirme süresinin artmasına bağlı olarak rengin koyulaşttğı, yeşilliğin arttı̆̆1 belirlenmiştir. Çimlenmemiş örnekler ile çimlendirme işlemi uygulanmış örnekler kıyaslandığında; çimlenme ile birlikte kül, ham protein, ham yağ ve toplam fenolik madde miktarlarının arttığı, fitik asit miktarının ise azaldığı $(P<0.05)$ tespit edilmiştir. Dolayısıyla çimlendirme işlemi ile tanelerin besinsel ve fonksiyonel içeriklerinde meydana gelen olumlu değişmeler, çimlendirme prosesinin önemini daha da arttırmaktadır. Çimlendirme ile tanelerinin bünyelerinde depo edilen maddeler, bir yandan parçalanırken, öte yandan da yeni bileşiklere sentezlenmekte ve böylelikle tanelerin mineral, fenolik madde, ham yağ ve protein içerikleri değişmektedir.

\section{KAYNAKLAR}

AACC (1990). American Association of Cereal Chemists, Approved Methods of the AACC. $8^{\text {th }}$ Edition, Saint Paul, Minnesota, USA.

Alvarez-Jubete, L., Wijngaard, H., Arendt, E.K., Gallagher, E. (2010). Polyphenol composition and in vitro antioxidant activity of amaranth, quinoa buckwheat and wheat as affected by sprouting and baking. Food Chem, 119(2): 770778.

Arslan, M. (2010). Çeşitli şiddetteki gök gürültüsü seslerinin tohum çimlenmesi üzerine etkileri. Dumlupınar Üniversitesi Fen Bilimleri Enstitüsü Biyoloji Anabilim Dalı Yüksek Lisans Tezi, Kütahya, 42 s.

Ashton, W.M., Williams, P.C. (1958). The phosphorus compounds of oats the content of phytate phosphorus. J Sci Food Agric, 9(8): 505511. 
Bibi, N., Aurang, Z., Amal, B.K., Mohammad, S.K. (2008). Effect of germination time and type of illumination on proximate composition of chickpea seed (Cicer arietinum L.). Am J Food Technol, 3(1): 24-32.

Chauhan, A., Saxena, D.C., Singh, S. (2015). Total dietary fibre and antioxidant activity of gluten free cookies made from raw and germinated amaranth (Amaranthus spp.) flour. Lwt-Food Sci Technol, 63(2): 939-945.

Dilber, A., Türker, S., Elgün, A. (2003) Çimlendirilmiş bir buğday ürünü olan azı üzerine araştırmalar. Gıda, 28(4): 409-414.

Donkor, O.N., Stojanovska, L., Ginn, P., Ashton, J., Vasiljevic, T. (2012). Germinated grainssources of bioactive compounds. Food Chem, 135(3): 950-959.

Duranti, M., Gius, C. (1997). Legume seeds: protein content and nutritional value. Field Crops Res, 53(1-3): 31-45.

Düzgüneş, O., Kesici, T., Kavuncu, O., Gürbüz, F. (1987). Araştırma ve Deneme Metodlar. Ankara Üniversitesi Ziraat Fakültesi Yayınlanı, Yayın No: 1021, Ankara, 381 s.

Dziki, D., Gawlik-Dziki, U., Kordowska-Wiater, M., DomaN-Pytka, M. (2015). Influence of elicitation and germination conditions on biological activity of wheat sprouts. J Chem, vol2015: 1-8.

El-Adawy, T.A., Rahma, E.H., El-Bedawey, A.A., El-Beltagy, A.E. (2003). Nutritional potential and functional properties of germinated mung bean, pea and lentil seeds. Plant Foods Hum Nutr, 58(3): 1-13.

Ertaş, N. (2007). Yemeklik baklagiller ve antibesinsel faktörler. Selcuk Tarm Bil Der, 21(41): 85-95.

Evenari, M. (1984). Seed physilogy: from ovule to maturing seed. Bot Rev, 50(2): 143-170.

Farooqui, A.S., Syed, H.M., Talpade, N.N., Sontakke, M.D., Ghatge, P.U. (2018). Influence of germination on chemical and nutritional properties of barley flour. J Pharmacogn Phytochem, 7(2): 3855-3858.
Francis, F.J. (1998). Colour analysis. Nielsen Food Analysis Aspen Publishers, Maryland, USA, s. 599-612.

Finney, P.L. (1983). Effect of germination on cereal and legume nutrients changes and food or feed value: A comprehesive review. Rec $A d v$ Phytochem, 17: 229-305.

Fouad, A.A., Ali Rehab, F.M. (2015). Effect of germination time on proximate analysis, bioactive compounds and antioxidant activity of lentil (lens culinaris medik.) sprouts. Acta Sci Pol Technol, 14(3): 233-246.

Fratianni, F., Cardinale, F., Cozzolino, A., Granese, T., Albanese, D., Matteo, M., Zaccardelli, M., Coppola, R., Nazzaro, F. (2014). Polyphenol composition and antioxidant activity of different grass pea (Lathyrus sativus), lentils (Lens culinaris), and chickpea (Cicer arietinum) ecotypes of the Campania region (Southern Italy). J Funct Food, 7: 551-557.

Gamez-Meza, N., Noriega-Rodriguez, J.A., Medina-Juarez, L.A., Ortega Garcia, J., CazarezCasanova, R., Angulo-Guerrero, O. (1999). Antioxidant activity in soybean oil of extracts from thompson grape bagasse. J Am Oil Chem Soc, 76: 1445-1447.

Garciarubio, A., Legaria, J.P., Covarrubies, A.A. (1997). Abscisic acid inhibit germination of mature arabidopsis seeds by limiting the availabity of energy and nutrients. Planta, 203(2): 182-187.

Ghavidel, R.A., Prakash, J. (2007). The impact of germination and dehulling on nutrients, antinutrients, in vitro iron and calcium bioavailability and in vitro starch and protein digestibility of some legume seeds. Lwt-Food Sci Technol, 40(7): 1292-1299.

Gül H., Hayıt F., Acar C., Kurt N., Dizlek H. (2018). Effects of chickpea-based leavening extract on physical, textural and sensory properties of white wheat bread. Int J Food Eng, 14(5-6): 1-11.

Harmuth-Hoene, A.E., Bognar, A.E., Kornemann, U., Diehl, J.F. (1987) The influence of germination on the nutritional value of wheat, 
mung beans and chickpeas. Z Lebensm Unters Forsch, 185(5): 386-393.

Haug, W., Lantzsch, H.J. (1983). Sensitive method for the rapid determination of phytate in cereals and cereal product. J Sci Food Agric, 34(12): 1423-1426.

Jones, R.L., Jacobsen, J.V. (1991). Regulation and syhntesis and transport of secreted proteins of in cereal aleurone. Int Rev Cytol, 126: 49-88.

Kanmaz, E.Ö., Ova, G. (2014). Filizlenme işleminin fitokimyasal bileşikler üzerine etkisi. Grda, 39(1): 49-56.

Kanmaz, E.Ö. (2017). Fonksiyonel Antioksidan Gudalar: Yenilebilir tohum filizleri. Sidas Medya, İzmir, 256 sayfa.

Karaşahin, M. (2015). Topraksız ortamda yetiştirilen bazı tahılların çim suyu verim ve besin değerleri. Iğdır Univ J Inst Sci Tech, 5(4): 57-64.

Kavas, A., El, S.N. (1991). Nutritive value of germinated mung beans and lentils. J Consumer Stud Home Econ, 15(4): 357-366.

Kim, D.K., Jeong, S.C., Gorinstein, S., Chon, S.U. (2012). Total polyphenols, antioxidant and antiproliferative activities of different extracts in mungbean seeds and sprouts. Plant Foods Hum Nutr, 67(1): 71-75.

Mahmoud, A.H., El-Anany, A.M. (2014). Nutritional and sensory evaluation of a complementary food formulated from rice, faba beans, sweet potato fl our, and peanut oil. Food Nutr Bull, 35 (4), 403-413.

Martinez-Villaluenga, C., Frias, J., Gulewicz, P., Gulewisz, K., Vidal-Valverde, C. (2008). Food safety evaluation of broccoli and radish sprouts, Food Chem Toxicol, 46(5): 1635-1644.

Márton, M., Mándoki, Z., Csapo-Kiss, Z.S., Csapo, J. (2010). The role of sprouts in human nutrition, A review. Acta Univ Sapientiae, 3, 81-117.

Narsih, Y. (2012). The study of germination and soaking time to improve nutritional quality of sorghum seed, Int Food Res J, 19(4): 1429-1432.
Nonogaki, H., Bassel, G.W., Bewley, J.D. (2010). Germination-still a mystery. Plant Sci, 179(6): 574581.

Öztürk, İ. (2008). Çimlendirilmiş buğday tanesinin kimyasal özelliklerinin belirlenmesi ve doğal katk1 maddesi olarak değerlendirilme imkanlarının araştırılması. Erciyes Üniversitesi Fen Bilimleri Enstitüsü G1da Mühendisliği Anabilim Dalı Yüksek Lisans Tezi, Kayseri, $121 \mathrm{~s}$.

Pasko, P., Barton, H., Zagrodzki, P., Gorinstein, S., Folta, M., Zachwieja, Z. (2009). Anthocyanins, total polyphenols and antioxidant activity in amaranth and quinoa seeds and sprouts during their growth. Food Chem, 115(3): 994-998.

Randhir, R., Lin, Y.T., Shetty, K. (2004). Stimulation of phenolics, antioxidant and antimicrobial activities in dark germinated mung bean sprouts in response to peptide and phytochemical elicitors. Process Biochem, 39(5): 637646.

Siro', I., Ka'polna, E., Ka'polna, B., Lugasi, A. (2008). Functional food: product development, marketing and consumer acceptance- A review. Appetite, 51(3): 456-467.

Slinkard, K., Singelton, V.L. (1977). Total phenolic analysis, automation and comparison with manual methods. Am Enol Vitic, 28(1): 4955.

Sneath, R. Mclntosh, F. (2003). Review of Hydroponic Fodder Production for Beef Cattle. Queensland Government, Department of Primary Industries, Dalby, Queensland.

Tangüler, H., Eleroğlu, H., Özer, E.A., Işıklı, N.D. (2015). Unutulmak üzere olan geleneksel tatlımız: Uğut. TURJAF, 3(7): 604-609.

Tian, B., Xie, B., Shi, J., Wu, J., Cai, Y., Xu, T., Xue, S., Deng, Q. (2010). Physicochemical changes of oat seeds during germination. Food Chem, 119(3): 1195-1200.

Tok, H. (2017). Tahıl ve baklagil çimlerinin ekmek ve bisküvi üretiminde kullanım olanakları. Necmettin Erbakan Üniversitesi Fen Bilimleri Enstitüsü Gıda Mühendisliği Anabilim Dalı, Yüksek Lisans Tezi, Konya, 141 s. 
Uppal, V., Bains, K. (2012). Effect of germination periods and hydrothermal treatments on in vitro protein and starch digestibility of germinated legumes. J Food Sci Technol, 49(2): 184-191.

Xu, J.G., Tian, C.R., Hu, Q.P., Luo, J.Y., Wang, X.D., Tian, X.D. (2009). Dynamic changes in phenolic compounds and antioxidant activity in oats (Avena nuda L.) during steeping and germination. J Agric Food Chem, 57(21): 1039210398.

Xu, M.J., Dong, J.F., Zhu, M.Y. (2005). Effect of germination conditions on ascorbic acid level and yield of soybean sprout. J Sci Food Agric, 85(6): 943-947.
Yang, F., Basu, T.K., Ooraikul, B. (2001). Studies on germination condition and antioxidant contents of wheat grain. Int J Food Sci Nutr, 52(4): 319-330.

Yaqoob, S., Baba, W.N., Masoodi, F.A., Shafi, M., Bazaz, R. (2018). Effect of sprouting on cake quality from wheat-barley flour blends. J Food Meas Charact, 12(2): 1253-1265.

Yetim, H., Öztürk, İ., Törnük, F., Sağdıç, O., Hayta, M. (2010). Yenilebilir bitki ve tohum filizlerinin fonksiyonel özellikleri. Gıda, 35(3): 205-210. 